\title{
Contemporary Folk Law
}

The undersigned are in the process of forming a "Working Group on Folk Law" with the ultimate objective of forming a Commission affiliated with the I.A.U. Through the medium of Current Anthropology and the International Association of Legal Science we hope to reach social scientists and jurists who would be interested in cooperating with us in our efforts. We would like to briefly outline our ideas about the nature of the Working Group.

The Working Group's members should be devoted to the study of the theoretical, methodological, and practical aspects of folk law in pluralistic legal systems. We are sadly aware of the various connotations the word "folk law" carries, and we should like to stress that by using it we do not imply distinctions such as folk vs. urban, folk/traditional vs. nonfolk/modern. We only employ the word in want of a label which would more appropriately cover our field of interest.

We associate "folk law" with social phenomena on two levels:

1. On the one level, the one of the content of legal conceptions, we think of folk-law where the law of a society (or of one of society's subgroups) corresponds to that society's (that society's subgroup's) members' cognitive and normative conceptions.

2. Secondly, we think of folk law as involving social processes, namely those procedures and persons engaged in legally relevant actions legitimized by folk law in the first sense.

It is obvious that there is only an overlap between the folk law on these two levels: Folk law elements in the first sense are not restricted to the products of folk law processes but may also appear in other forms of law, e.g. in legislative enactments. Conversely, in folk law procedures, non-folk law conceptions may also be applied. It follows that when we speak of folk law, the label does not cover analytically distinct social phenomena. It is further clear to us that folk law cannot be studied and analyzed as an isolate but only as a component or aspect of a larger and generally pluralistic socio-legal system. However, there should be a common interest on the folk law elements which should unite the working Group's members.

These interests may briefly be outlined here. When we speak of the theoretical, methodological, and practical aspects of folk law, we think of the following:

- Theoretical aspects: What kind of social phenomena can ideally be distinguished as "folk law"; how does the partial supersession by or the incorporation into other forms of law affect the nature of folk law; how is folk law affected by its application in a diversity of "non-folk" administrative structures?

- Methodological aspects: Questions of the appropriate methods and techniques in literature- and field research; methods and doctrines of "law finding" in the processes of folk law application.

- Practical aspects: The importance of folk law as a means for social orientation and social control; the application of folk law in the diverse institutions of law application; the development of folk law as a process of adaptation and as directed legal development.

Regionally, the Working Group's field of study should not be limited to those (mainly "third world") countries where folk law constitutes a major component of the legal systems. It should also extend to western societies where elements of folk law play a considerable role in certain fields of social activity, corporate structures and among minority groups.

We think that the Working Group should devote particular attention to the practical implications and consequences of folk law studies, the foremost we consider to be: Problems concerning the application of folk law, the pertinent doctrines of law application, and the adaptive and manipulated development of folk law. This objective may well constitute the criterion according to which selection of possible members should proceed. Membership in the 
Working Group is not only open to social and legal scientists (who share our objectives?), but also to practitioners; c.q. judges and administrators concerned with the application and development of folk law.

Those who are interested in this field and who wish to join the Working Group, are called upon to inform the correspondence address given below.

F. von Benda Beckmann

$\mathrm{K}$. von Benda Beckmann-

Droogleever-Fortuyn

G.C.J.J. van den Bergh

Moh. Koesnoe

H. Slaats

K. Slaats-Portier

G. van den Steenhoven

A.K.J.M. Strijbosch

A.A. Trouwborst

Corr:

Institute of Folk Law

Oranjesingel 72

Nijmwegen, The Netherlands 